\title{
Human Capability and Entrepreneurial Development in the Niger Delta Region of Nigeria
}

\author{
Paul Oghenero Okumagba, Otega Okinono \\ Delta State University Abraka, Nigeria \\ Okumagba2012@gmail.com
}

\begin{abstract}
The paper sets out to explore the link existing between the entrepreneurial interventions and human capital development in Niger Delta Region of Nigeria. In order to address the major problem of the Niger Delta region of Nigeria, many successive governments in Nigeria have embarked on one entrepreneurship developmental program or the other. Unfortunately, all these government efforts have failed to yield a fruitful sustainable entrepreneurial development particularly among the Niger Delta region that are mainly the target of the programs. Past studies have attributed such failure to a range of factors such as infrastructure decay and deficiency leading to poor human development, lack of proper implementation of the master plan, lack of funds, inadequacy of the master plan etc. Although, the efforts of the past studies as well as that of the developmental agencies are commendable, however, they have failed to address one important issue which is the human capability aspect of the developmental program. Therefore, this paper explores the role of human capability approach on the effectiveness of the entrepreneurship development programs within the Niger Delta region context and the political influence with a view to proposing a framework to examine the relationship between human capability and effective entrepreneurship development programs.
\end{abstract}

Keywords: Human capability, Entrepreneurial development, programs, Niger Delta Region, Nigeria

\section{Introduction}

Entrepreneurship development has become a central issue of discussion in every government agenda in many countries of the world. Perhaps because of the significant role it plays in economic growth and development of a nation. According to Rebecca and Benjamin (2009), entrepreneurship development helps in the transformation of people's lives by equipping and empowering them for self-reliance and sustainability. Studies (Nwabufo \& Mamman, 2015; Oziegbe, Oleabhiele \& Adeyemo, 2015) have indicated that governments in developed and developing nations tend to promote entrepreneurship development amongst its citizens for improved well-being and living condition of her citizens. However, some countries particularly in the developing nations have not been able to achieve much success in sustainability of entrepreneurship development (Jamaluddin \& Dickie, 2011; Al Rabeei, 2003). This scenario captures the efforts of the Nigerian government in addressing the issue of human development through entrepreneurship programs particularly in the Niger Delta region. In line with the developmental agenda of the country, the development of the Niger Delta region has also been a paramount concern to the Nigerian government due to its contribution to the nation's economy (Amadi \& Abdullah, 2012).

Apart from this, the region is heavily suffering from the activities of the oil companies such as degradation, poverty and deprivation which are now making life unbearable for the local dwellers. Many have lost their farmlands, fishing occupation and the very means of their sustenance and livelihood (Ebegbulem, Ekpe and Adejumo, 2013; Mmom and Igwe, 2012), hence, the people's agitation for development. In order to address the plight of the people, the Nigerian government came up with various developmental initiatives through the establishments of different developmental boards like the Niger Delta Development Commission (NDDC), the Niger Delta Ministry and more recently the Amnesty programs. The philosophy behind the creation of these boards was to initiate development programs that will rejuvenate the region and empower the community members for self-sustainability (Agbiboa, 2013; Duru \& Ogbonnaya, 2012).Therefore, programs such as skill acquisition and training programs were established across the oil Niger Delta region. Although, the efforts of the Nigerian government are quite commendable, however, these programs were not sustained. Past studies (Okumagba, 2011; Mboho \& Iyang, 2011; Jack-Akhigbe, (2013) have revealed that the inability of the government to sustain development programs in the Niger Delta is attributed to lack of commitment, 
inadequate funding, corruption and political interference. Moreover, Omojimite (2011) argued that most of the programs initiated by the government are politically motivated for personal benefits and at the same time as a weapon to witch-hunt their political opponents. Similarly, Paki and Ebienfa (2011) contended that there is no autonomy of project executions by the agencies. They observed that the agencies are mainly concerned with project supervision but denied access to fund allocation for project implementation. This indicates that there is lack of coordination in the organizational structure and activities of the development agencies. Likewise Dopkesi and Ibiezugbe (2012) that noted development programs initiated by the government in the region are not sustained due to lack of community inputs in identification and implantation of programs.

A critical examination of the failures of these programs tends to point to the inability of the developmental agencies to identify and inculcate community need and interest in developmental initiatives particularly on the entrepreneurship development program (Akinola, 2012). Accordingly Alkire (2002) posits that when people are given opportunity and freedom to decide on issues that positively enhances their wellbeing, there is bound to be meaningful developmental. He termed this as human capability enhancement which promotes mental capacity development and training of the mind. The United Nations Development Report (UNDP, 2013) indicated vocational training as a platform that enables individual to exercise and maximize their potentials in achieving self-actualization and sustainability within their immediate environment and society at large. Past study such as Agbiboa (2013), Ajibola (2015), Ekumaoko (2013) have indicated that the training and empowerment programs initiated by the government were not targeted towards community development and empowerment but rather as a way of enticing the warring youths to drop their arms. Furthermore, Ubulom and Enyoghasim (2012),concluded that the developmental initiatives of the Nigerian government has the capacity to address the poor living condition of the people if and only if the developmental agencies can re-strategize their approach by adopting the human capability perspective for the effective entrepreneurial developmental programs of the Niger Delta region. This paper believes to a large extent that incorporating human capabilities into the entire entrepreneurial developmental programs of the Niger Delta region would go a long way to addressing the already created vacuum. In view of the above realities, this paper explains the role of human capability on the effectiveness of entrepreneurship developmental programs in the Niger Delta region of Nigeria with a view to proposing a framework to guide effective entrepreneurship developmental programs in the Niger Delta region.

\section{Literature Review and Concept Clarification}

Overview of NDDC and Human Development in the Niger Delta: The creation of NDDC is one of the efforts of Nigerian government to promote development in the Niger Delta region (Paki and Ebienfa, 2011; Okolo, 2014). NDDC is an acronym of Niger Delta Development Commission which was established by the former Nigeria President, Olusegun Obasanjo in (Ahonsi, 2011). The body was established with the objective of ensuring the overall development of the Niger Delta region. In other words, its agenda is to promote not only infrastructural development but also human development which is paramount to the people of the Niger Delta (Okafor, 2011; Aghalino, 2012). The human development agenda for the Niger Delta is borne out of lack of confidence of the people in the government as a result of the past failures and lapses displayed by the various past and present agencies set up by the government (Akpomuvie, 2011). The proposed agenda by NDDC though might not be the final solution to the developmental problem of the region; however, it will go a long way to reduce the level of agitations and rancor going on in the region. The NDDC developmental agenda aims to accomplish two goals; first physical development while the second to address those constrains that tends to distort human development Nwilo and Badejo (2005). Enshrined in the NDDC master plan are the various areas to be considered in this new agenda. Since then, the body has embarked on several human development projects and other developmental programs including entrepreneurial related programs such as empowerment programs and skill acquisition programs (Ndem, Michael and Awa, 2012). The NDDC agenda of human development is based on the belief that people are the most important and focal point of any development in the society. The human and capital resources invested in the establishment and operation of NDDC have made Niger Delta people to believe that their messiah has come to relief them of developmental pain being suffered for decades. The NDDC human development agenda has also directed attention to the provision of schools, scholarships bursary, skill acquisition programs to engender human developments in the Niger Delta region. It is in this view that Olley, (2011) suggested that NDDC human development program should not only focus on giving opportunity for education to the people but should 
also train people to be effective and functional in the society. However, a critical observation revealed that NDDC has concentrated more on physical development such as the physical infrastructures like roads and bridges rather than human development. Thus, the need to re-focus on development programs through the adoption of human capability approach leading to effective entrepreneurial development programs within the Niger Delta region.

Conceptual Framework and Clarification: In this study, passion, choice and skill demonstration are components of human capability. Therefore, human capability in this context is conceptualized as passion, choice and skill demonstration and these are discussed in line with entrepreneurship development.

Passion and entrepreneurship development: Generally, passion is described as a situation that warrants individual putting more energy into something than initially required. It goes beyond enthusiasm or excitement. Passion is not hobby as a hobby is just a dream. Passion has long been recognized as a central component of entrepreneurial motivation and success (Lam, 2015). Despite the virtually unchallenged view that passion is important for venture creation and growth, surprising little systematic theoretical or empirical work exists concerning the notion of passion and its influence on entrepreneurial activities (Hoang \& Yi, 2015; VanSledright, 2004). Therefore, in line with this study passion is conceptualized as individual's ambition materialized into action to put as much heart, mind body and soul into something as is possible. As it is, passion makes individual to work very hard in order for him to achieve his desire goals. For example, it is believed that when community members share a common passion and there are available resources to achieve their plan then development will be sustained. However, Dissanayake, (2014) argued that it is not in all cases that community members will share common passion and interest before achieving development. Sometimes, diversity might lead to sense of belonging in community and social identity. The most important element is giving control and decision making to community members because they are the ones that are mostly affected. This is because neither governments nor non-governmental agencies have the capabilities to solve and sustain all the difficulties and problems within a community hence it is vital to involve community members in issues that affect them (Magis, 2010). Also, individual with passion may outperform the person without passion. Passion is a catalyst that propels individuals to take over the wheel and do things that challenge the status quo, push boundaries and ultimately reshape the world as we knew it. To strive for passion is to be different from the rest and that is entrepreneurship development. Passion therefore makes people better entrepreneurs than the others. Therefore, passion for entrepreneurship development brings out the best out the person likewise the common passion for the community would also help them to achieve the community basic objectives. Hence, a strong correlation exists between passion and entrepreneurship development.

Choice and entrepreneurship development: The following words such as options, alternative and preference can be used to connote choice. In management, choice is commonly described as choosing from many alternatives. Within the context of this study, choice is conceptualized as the availability of many options and alternatives to entrepreneurial activities and programs. Block, Hoogerheide and Thurik (2009) on the study of education and entrepreneurial choice: an instrumental variables analysis claimed that entrepreneurial choice is likely to take place among those people with higher level of education. In other words, the higher the respondent's level of education, the greater the likelihood that he/she starts a business. Accordingly, Fossen and Steiner (2006) investigated the relationship between income taxes and entrepreneurial choices in Germany and found that the decrease in tax rates was not significantly related to self-employment decision. A similar research by Fossen (2008) on the tax policy, risk and entrepreneurial choice in Germany revealed that entrepreneurial choice is subject to tax rates in Germany. On the opposite, they also found that the effects on the exit rate from self-employment are small in relative terms and statistically insignificant, both for the full sample and the sample of men. The studies above clearly show that individual choices play significant role in matters concerning taxes, self-employment, risk taking which are all parts of entrepreneurship development. It is also clear that people tend to do better in their choosing profession or career when they are given the opportunity to make choice or choose what they want to do. Hence, there is a strong correlation between choice and entrepreneurship development. In this case, the developmental agency such as NDDC should learn how to give individual participating in their training and acquisition program to make choices of what area of entrepreneurial activity or program they desire or want. 
Skill Demonstration and Entrepreneurship Development: Based on D'Amico, Tucker, Miles, Zhou, Shih and Green (2012). There is no consensus on what the definition of skill should be. However, Kelley, O'Connor, Neck and Peters (2011) described skill as the ability and capacity to do something. Wickham (2006) also defined skill as the knowledge that is best described by an action. Also, business dictionary.com describes skill as the ability and capacities obtained via deliberate systematic and sustained effort to smoothly and adaptively execute compound and difficult tasks which required technicalities. Holding on these descriptions above, this paper therefore conceptualized skill demonstration as the application of acquire skill and knowledge to achieve the desire goals. It is also the platform whereby those who acquired the entrepreneurial skills through the various skill acquisition centers showcase their knowledge and skills they have acquired in their training. Previous authors on entrepreneurship development have affirmed that individual skills generally predict entrepreneurial activities. For instance, Ahmad and Seet (2010) in their study claimed that entrepreneurial skills are strongly related to the entrepreneurial intention of the foreign students in Malaysia. Kuratko and Hodgetts (2004) have long identified skill as a key factor to successful and meaningful entrepreneurial development. Also, Metzler and Woessmann, (2012) found that skill is significantly related to the teacher's performance. They concur that skill plays a significant role in the development of qualified teaching profession. This paper goes beyond the previous studies by discussing on the demonstration of entrepreneurial skills. It is the belief of this paper that it is not just enough for people to acquire skills but must demonstrate these skill. Therefore, there should be a platform where people with the acquired skill should be given the opportunity to exhibit and practically use the skills, and by so doing, the skills be acquired can become part of them for live and also make them productive and useful to themselves and society. Therefore, there is need for NDDC to engage in practical skill demonstration through the provision of appropriate channel and environment to enhance entrepreneurship development in the Niger Delta region.

Human Capability and Entrepreneurship Development: First capability is the ability to perform or achieve certain actions or outcomes through a set of controllable and measurable factors, features, processes or services (Sen, 2005). Human capability is concerned with the training, lubricating of the mind, developing mental capacity and provision of vocational training which at the long run enables individual to achieve freedom in a society (UNDP, 2013). Capability is the ability to perform or achieve certain actions or outcomes through a set of controllable and measurable factors, features, processes or services (Amartya, 2005). There is no gain saying that human development can only be achieved when consideration is given to what people are actively capable of doing or becoming if given the opportunity. Individuals are considered as an end, with the ability for choices and freedom among a variety of values (Dopkesi \& Ibiezugbe 2012). Capability is one of the individual's traits or characteristics identified by the psychological theory that aid entrepreneurship development (Duxbury, 2012; Okhomina, 2010).Capability helps an individual not only to do the job but to do the job very well. Kuratko and Hodgetts (2004) in their work identified capability as entrepreneur's attribute that can foster entrepreneurship development. The study by Lichtenthaler, Muethel (2012) highlighted the importance of capability which they called capacity. The found that mental capacity of the entrepreneur aid entrepreneurship development thereby affecting the firm performance.

Owing to this, the developmental agency such as NDDC should support the development of capabilities, but not influence their functioning giving individual's freedom to choose how to exercise and maximize their potentials. To date, development choices have failed to stimulate people into optimally productive activities most especially in display of skills and expansion of their abilities. The human development agenda is a people-centered development that seeks to remove obstacles that prevent people from achieving their full potentials and to empower people particularly at the grass root and on the margins of society should be targeted towards reducing inequalities of all kinds, including those relative location, gender and generation and to enlarge peoples choices in the economic, political and socio-cultural domain (Chandler, 2013). A human development agenda could transform the Niger Delta into a region that is economically, socially and politically stable; ecologically rejuvenating that will ensure rapid, equitable and sustainable development.

Entrepreneurship Development: In an attempt to describe entrepreneurship development, Ogundele, Akingbade \& Akinlabi (2012) described entrepreneurship as a process that involves entrepreneur recognizing opportunities within the environment, mobilizing resources to take advantage of such opportunities in order to provide improved goods and services for the consumers and awarding reward for 
risk taken. This demonstrates that entrepreneurship is all about environmental opportunities waiting to be utilized and harnessed by entrepreneurs. Also, Alvarez, Barney and Anderson, (2013) described entrepreneurship as a process whereby individual's independently discover, evaluate and exploit opportunities within their immediate environment. In the view of Rebecca and Benjamin (2009), entrepreneurship development entails a creative process of organizing, managing enterprises and assuming the risk involved in the enterprise.

\section{Figure 1: Conceptual Model}

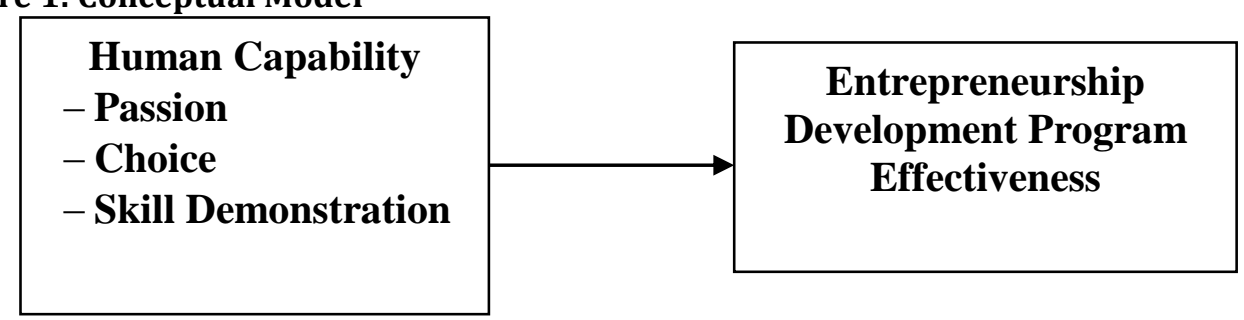

Based on the literature review and coupled with the conceptual model above, the study proposed as follows: Proposition: Human capability is positively related to entrepreneurship development programs.

\section{Theoretical Framework}

Two major theories were adopted to underpin the present study. These theories include the theory of human capability and the psychologist perspective of entrepreneurship theory by McClelland (1961). Human development and capability building defines the process by which society appropriates the natural demography to its advantage for development (Nussbaum, 2001). The theory of human capability posits that without capability of people, no meaningful developmental can be achieved (Alkire, 2002). This is because it is only human capability that trains and loosens the mind, develops mental capacity and provides vocational training which at the long run enables individual to achieve freedom in a society (UNDP, 2013).Capability of any person can be enhanced through several means such as education, training, skill acquisition and rehabilitation (Edyburn, 2013; Schwarzer, 2014). If capability is adequately enhanced and incorporated into the Niger Delta people entrepreneurial developmental program, then it may enlarge their opportunities in all aspects of human endeavor that would equally lead to effective entrepreneurial programs (Wodi, 2012).

Furthermore, according to the psychologist perspective of entrepreneurship theory by McClelland (1961) which is also referred to as heredity or traits theory, it emphasizes the traits or attributes that an individual possesses that enable them to function properly in the entrepreneurial activities or engagement. Thus, psychologists concentrate on the characteristics and personality of an individual that form a business. These authors associated successful entrepreneurship development with certain individual characteristics or traits or attributes of a person. Among these individual traits or attributes is capability. According to Timmons (1999), individual must possess the capability and ability to create and build a vision from practically nothing. The trait theory which posits that individual performs well due to their internal traits which are viewed as hereditary Petrides and Furnham (2015), McClelland (1961) is of the view that the key to entrepreneurial behavior lies in achievement motivation perhaps propel by capability. The need to achieve is a drive to excel, to achieve a goal in relation to a set of standards. A person endowed with a need to achieve, will spend time considering how to do a job better or how to accomplish something important to them and this is called capability which needed to be incorporated into Niger Delta region entrepreneurial program for better effectiveness. Therefore, sustainable entrepreneurship development among the Niger Delta regions is a function of their personal characteristics or traits. The Psychology Theory assumes that there are some distinguished psychological and demographic characteristics individuals should possess for effective performance (Cherry, 2012). An effective entrepreneurial development program would require a situation where the Niger Delta people can take personal responsibility to find a solution to their problem, avoid what they perceive to be very easy or very difficult task and prefer to strive to achieve target, which is challenging and is not beyond their capabilities. 
Building on the existing knowledge of psychology theory of entrepreneurship and human capability theory, this paper assumed that a strong correlation exist between human capability and effective entrepreneurial development programs. This is also depicted in figure 1, where it is demonstrated that human capability in the form of passion, choice and skill demonstration will positively predict effective entrepreneurship development programs. In other words, effective entrepreneurship development program in the Niger Delta will be visible if the people with passion are allowed to make their choices on what area of entrepreneurship training and skill they need and then given the platform to exhibit or demonstrate these skills they have acquired. Thus, effective entrepreneurship development programs in the Niger Delta can only be meaningful when people are given the opportunity to actively participate and make choices and decisions that will positively affect their lives (Chandler, 2013). Thus, the needs and interests of the region must be put into consideration in the entire entrepreneurial programs through the building of human capability that comprises of passion, choice and platform for demonstration of their skills.

\section{Conclusion}

The objective of this paper is to critically examine human capability and entrepreneurship development in the Niger Delta region of Nigeria. The paper argued that human capability approach is required to address the gap in the entrepreneurship development program in the Niger Delta region. Therefore, there is a need to consider human capability aspect of the people in the training and developmental programs targeted at them. The paper views human capability as the core value in achieving one's ends in a particular society that enlarges the choices of individuals'. This aspect found to be lacking in the entrepreneurship and overall developmental approach used in the Niger Delta region of Nigeria. Apart from the fact that both the trait and human capability theories stress on the need to identify peoples' capability and utilize it in the process of any form of development including the entrepreneurship development. For example, Timmons (1999) stated that individual must possess the capability and ability to create and build a vision from practically nothing. The trait theory also posits that individual performs well due to their internal traits and one of such is capability. A sustainable development would require a situation where the Niger Delta people can take personal responsibility to find a solution to their problem through the adoption of strategic developmental approach that recognizes the role of individuals in developmental skills. This can be attainable if the NDDC can adopt human capability approach in the training and development of the Niger Delta people. The human capability should take cognizance of passion, choice and platform for demonstration of the skills acquired in the entrepreneurial development programs. In conclusion, the paper provided a theoretical insight into the human capability approach as a means for achieving effective entrepreneurial developmental programs in the Niger Delta region of Nigeria. It has managed to provide theoretical evidence that human capability approach is correlated with entrepreneurial development program effectiveness, and therefore should be incorporated into the entire training and development programs targeted at the Niger Delta people. This is also postulated by the psychology and human capability theories that capabilities of individuals are very crucial in achieving a fruitful development including entrepreneurial programs.

Implication of Study: The paper contributes to body of knowledge by proposing a conceptual framework to empirically examine the effectiveness of entrepreneurial developmental programs in communities not only in the Niger Delta regions but also other communities experiencing similar situation across the globe. Academically speaking, the study's insights should contribute to the future development of this line of research, particularly in a developing country like Nigeria. Therefore, the paper is of significant value to practitioners and scholars alike.

Limitation and Suggestion for Further Study: One major limitation to this study is as a result of its theoretical nature which did not provide the opportunity to draw empirical conclusion on the issue of human capability and entrepreneurship development. In other words, the paper is theoretically based without any empirical fact. Therefore, this paper suggests that empirical investigation should be conducted by other studies. 


\section{References}

Agbiboa, D. E. (2013). Have we heard the last? Oil, environmental insecurity, and the impact of the amnesty program on the Niger Delta resistance movement. Review of African Political Economy, 40(137), 447465.

Aghalino, S. O. (2012). Brief but revolutionary: Yar'Adua and sustainable development of the Niger Delta, Nigeria. Global Advance Research Journal of History, Political Science and International Relations 1(6), 144-151.

Ahmad, N. H. \& Seet, P. S. (2010). Gender variations in ethical and socially responsible considerations among SME entrepreneurs in Malaysia. International Journal of Business and Society, 11(1), 77.

Ahonsi, B. (2011). Capacity and governance deficits in response to the Niger Delta crisis. Oil and Insurgency in the Niger Delta: managing the complex politics of petro-violence. London and New York NY: Zed Books.

AI-Rabeei, H. (2003). The Future of Entrepreneurship and SME's in Bahrain\|. World Conference International Council for Small Business, 48th International Council for Small Business (ICSB) World Conference 2003.

Amadi, B. O. \& Abdullah, H. (2012). Poverty alleviation through corporate social responsibility in Niger Delta, Nigeria. Asian Social Science, 8(4), 57.

Ajibola, I. O. (2015). Nigeria's amnesty program. SAGE Open, 5(3), 2158244015589996.

Akinola, S. R. (2012). Overcoming tyranny and underdevelopment in the Niger Delta through appropriate human resources development and utilization, natural resources, Conflict and Sustainable Development: Lessons from the Niger Delta, 59-86.

Akpomuvie, B. O. (2011). Breaking Barriers to transformation of the Niger Delta Region of Nigeria. A Human Development Paradigm Journal of Sustainable, 4 (3), 1 - 15.

Alkire, S. (2002). Dimensions of human development. World development, 30(2), 181-205.

Alvarez, S. A., Barney, J. B. \& Anderson, P. (2013). Forming and exploiting opportunities: The implications of discovery and creation processes for entrepreneurial and organizational research. Organization Science, 24(1), 301-317.

Amartya, S. (2005). Human Rights and Capabilities. Journal of Human Development, 6(2). Routledge. Publishers.

Block, J. H., Hoogerheide, L. \& Thurik, R. (2009). Education and entrepreneurial choice: an instrumental variables analysis claimed that entrepreneurial choice. Tinbergen Institute Discussion Paper. I 2009$088 / 4$.

Chandler, K. (2013). Human-centered Development? Rethinking freedom and Agency in discourses of International Development. SAGE Publications ltd.

Cherry, K. (2012). What is personality? Available online at: http://psychology.about.com/od/ competence and lecturer performance in higher institutions in Nigeria. Int. J. Management in Education, 9(2), 129150.

D’Amico, E. J., Tucker, J. S., Miles, J. N., Zhou, A. J., Shih, R. A. \& Green Jr, H. D. (2012). Preventing alcohol use with a voluntary after-school program for middle school students: Results from a cluster randomized controlled trial of CHOICE. Prevention Science, 13(4), 415-425.

Dissanayake, S. A. D. D. P. (2014). Empowering Communities or Creating Dependencies: People's Experience of a Development Project in Sri Lanka a Thesis Submitted to the Graduate School (Doctoral Dissertation, Ball State University).

Dopkesi, A. 0. \& Ibiezugbe, M. I. (2012). Assessing the human development efforts of the Niger Delta Development Comission. Natural Resources, Conflict, and Sustainable Development: Lessons from the Niger Delta. New York: Routledge, 60-78.

Duru, E. J. \& Ogbonnaya, U. M. (2012). The Poverty of Crisis Management Strategies in the Niger Delta Region of Nigeria: A Focus on the Amnesty Program. African Research Review, 6(2), 162-170.

Duxbury, T. (2012). Creativity: Linking Theory and Practice for Entrepreneurs. Technology Innovation Management Review, 2(8).

Ebegbulem, J., Ekpe, D. \& Adejumo, T. 0. (2013). Oil Exploration and Poverty in the Niger Delta Region of Nigeria: A Critical Analysis. International Journal of Business and Social Science, 4(3), 279-287.

Edyburn, D. L. (2013). Critical issues in advancing the special education technology evidence base. Exceptional Children, 80(1), 7. 
Ekumaoko, C. E. (2013). The amnesty question in post-conflict Niger Delta and peacebuilding. Arabian Journal of Business and Management Review, 2(10), 1-12.

Fossen, F. M. (2008). Tax policy, risk and entrepreneurial choice - empirical evidence from Germany.

Fossen, F. M. \& Steiner, V. (2006). Income taxes and entrepreneurial choice: Empirical evidence from germany.IZA Discussion Paper No. 2164.

Hoang, H. \& Yi, A. (2015). Network-based Research in Entrepreneurship: A Decade in Review. Foundations and Trends (R) in Entrepreneurship, 11(1), 1-54.

Ibrahim, N. A. \& Lucky, E. O. I. (2014). Relationship between Entrepreneurial Orientation, Entrepreneurial Skills, Environmental Factor and Entrepreneurial Intention among Nigerian Students in UUM. Entrepreneurship and Innovation Management Journal, 2(4), 203-213.

Jack-Akhigbe, P. (2013). The state and development interventions in the Niger Delta region of Nigeria. International Journal of Humanities and Social Science, 3(10).

Jamaluddin, A. \& Dickie, C. (2011).Decision-making related to business growth: Malay small business in Selangor. International Journal of Business and Management, 6(10), 284-296.

Kelley, D. J., O'Connor, G. C., Neck, H., \& Peters, L. (2011). Building an organizational capability for radical innovation: The direct managerial role. Journal of Engineering and Technology Management, 28(4), 249-267.

Kuratko, D. \& Hodgetts, R. (2004). Innovation and the entrepreneur. Entrepreneurship, 3, 138-150.

Lam, A. (2015). Academic scientists and knowledge commercialization: self-determination and diverse motivations. In Incentives and Performance (pp. 173-187). Springer International Publishing.

Lichtenthaler, U. \& Muethel, M. (2012). Retracted: The role of deliberate and experiential learning in developing capabilities: Insights from technology licensing. Journal of Engineering and Technology Management, 29(2), 187-209.

Magis, K. (2010). Community resilience: an indicator of social sustainability. Society and Natural Resources, 23(5), 401-416.

Mboho \& Inyang (2011). Institutional failures and poverty in the Niger Delta Region: A critical Appraisal of NDDC projects in Ikot Abasi, Akwa-Ibom State Nigeria International

McClelland, D. C. (1961).The achieving society. Free Press, New York.

Metzler, J. \& Woessmann, L. (2012). The impact of teacher subject knowledge on student achievement: Evidence from within-teacher within-student variation. Journal of Development Economics, 99(2), 486-496.

Mmom, P. C. \& Igwe, C. F. (2012). Environmental degradation resulting from oil exploitation, and population displacement in the Niger Delta, Nigeria. Journal of Environmental Science and Engineering, 1(1), 127138.

Ndem, B. E., Michael, B. \& Awa, O. C. (2012). Social capital, corruption and economic growth in Nigeria: A case study of some contracts awarded by Niger delta development commission in akwaibom and cross river state. Journal of Economics and Sustainable Development, 3(11), 53-63.

Niger Delta Region Development Commission. (2005). Draft copy of the Niger Delta Regional Development Master Plan. NDDC. Retrieved on $2^{\text {nd }}$ March 2014 fromwww.nddconline.org Nigeria's Niger Delta. International Journal of Business and Social Sciences, 2(8).

Nussbaum, M. C. (2001). Women and human development: The capabilities approach. Cambridge University Press.

Nwabufo, N. \& Mamman, J. (2015) Entrepreneurship education: a panacea for curbing graduate unemployment in Nigeria. International Journal of Teaching and Education, 3(3), 68-74.

Nwilo, P. C. \& Badejo, O. T. (2005). Oil spill problems and management in the Niger Delta. International Oil Spill Conference 1, 567-570). American Petroleum Institute.

Ogundele, O. J. K., Akingbade, W. A. \& Akinlabi, H. B. (2012). Entrepreneurship training and education as strategic tools for poverty alleviation in Nigeria. American International Journal of Contemporary Research, 2(1), 148-156.

Okafor, E. E. (2011). Dynamics of Niger Delta struggles and the State responses: the state of terrorism and terrorism of the State. Journal of Sustainable Development in Africa, 13(2), 88-105.

Okhomina, D. (2010). Entrepreneurial orientation and psychological traits: the moderating influence of supportive environment. Journal of Behavioral Studies in Business, 2, 1-16.

Okolo, P. O. (2014). NDDC, Conflict, Peace-Building and Community Development in the Niger Delta Region. Global Journal of Political Science and Administration, 2(1), 36-51. 
Okumagba, P. (2011). Oil Exploration and Ethnic Militia activities in the Niger Delta Region of Nigeria. African Research Review, 5(5), 56-67.

Olley, O. (2011). The Role Of Local Government In Rural Development: A Study of Warri North Local Government Area of Delta State (Doctoral dissertation, University of Nigeria, Nsukka).

Omojimite, B. U. (2011). Building Human Capital for Sustainable Economic Development in Nigeria. Journal of Sustainable Development, 4(4), p183. Overview of personality/a/persondef.htm (accessed on 20 August 2012).

Oziegbe, O. E., Oleabhiele, E. P. \& Adeyemo, A. D. (2015). Entrepreneurship Education and Sustainable Development. Academic Research International, 6(2), 279.

Paki, F. \& Ebienfa, K. (2011). Oil and Development Deficit in Africa: The failure of intervention agencies in Nigeria's Niger Delta. International Journal of Business and Social Science, 2(8), 133-140.

Petrides, K. V. \& Furnham, A. (2015). Further Tests of Belief-Importance Theory. PloS one, 10(4).

Rebecca, E. O. \& Benjamin, J. I. (2009). Entrepreneurial competencies: the missing links to successful entrepreneurship in Nigeria. International Business Research, 2(2), 62-71.

Schwarzer, R. (2014). Self-efficacy: Thought control of action. Taylor\& Francis.

Sen, A. (2005). Human rights and capabilities. Journal of Human Development, 6(2), 151-166.

Timmons, J. A. (1999). New Venture Creation. Fourth Edition. Illinois: Homewood.

Ubulom, W. J. \& Enyoghasim, M. (2012).Developing entrepreneurial skills through business education program to curb youth restiveness for sustainable Niger Delta development. European Journal of Business and Management, 4(21), 68-75.

UNDP. (2013). Human Development Report 2013: The Rise of the South: Human Progress in a Diverse World. Explanatory note on 2013 HDR composite indices, Guatemala. Retrieved on the $27^{\text {th }}$ September 2015 from http://hdrstats.undp.org/images/explanations/GTM.pdf

VanSledright, B. (2004). What does it mean to think historically... and how do you teach it. Social Education, $68(3), 230-233$.

Wickham, P. A. (2006). Strategic entrepreneurship. Pearson Education.

Wodi, S. W. (2012). Global economic crisis: A challenge to the entrepreneurship development of technical vocational education and training in oil and gas sector of the Nigerian economy. International Journal of Academic Research in Business and Social Sciences, 2(4). 